\title{
Analysis of student motivation towards body expression through the use of formative and share assessment \\ Análisis de la motivación del alumnado hacia la expresión corporal a través del uso de la evaluación formativa y compartida \\ Daniel Bores-García*, David Hortigüela-Alcalá**, Alejandra Hernando-Garijo**, Gustavo González-Calvo*** \\ *Universidad Rey Juan Carlos, ** Universidad de Burgos, *** U niversidad deValladolid
}

\begin{abstract}
The present article aims to investigate the influence of the use of formative and shared assessment processes on students' motivation and their level of commitment towards body expression contents in the Physical Education subject. 182 students with ages ranging from 12-13 years old participated in a study that was developed al ong a didactic unit of corporal expression. Following a qual itative methodology, data was obtained through the obser vation of individual student diaries, the teacher's diary and a focus group. The results show that a correct use of formative and shared evaluation increases students' motivation to develop expressive contents as well as their individual and group commitment. Students being able to choose their own teams, the greater amount of freedom that the creative methodology offers them, the permanent knowledge of what is demanded from the student, the playful aspect of the contents, and the provision of feedback are some of the factors that influence increased motivation and commitment levels from students.
\end{abstract}

Keywords: physical education; commitment; intrinsic motivation; triadic assessment.

Resumen: El presente artículo tiene como objetivo investigar la influencia del uso de los procesos de evaluación formativa y compartida en la motivación de los estudiantes y su nivel de compromiso con los contenidos de expresión corporal en la asignatura de Educación Física. 182 estudiantes con edades comprendidas entre los 12 y 13 años participaron en un estudio que se desarrolló a lo largo de una unidad didáctica de expresión corporal. Siguiendo una metodología cual itativa, los datos se obtuvieron mediante la observación de los diarios individuales de los estudiantes, el diario del profesor y un grupo de discusión. Los resultados muestran que un uso correcto de la eval uación formativay compartida aumentalamotivación de los estudiantes para desarrollar contenidos expresivos, así como su compromiso individual y grupal. La posibilidad de que los estudiantes elijan sus propios equipos, la mayor libertad que les ofrece la metodología creativa, el conocimiento permanente de lo que se exige al estudiante, el aspecto lúdico de los contenidos y la administración de retroal imentación son al gunos de los factores que influyen en el aumento de los niveles de motivación y compromiso de los estudiantes.

Palabras clave: educación física; compromiso; motivación intrínseca; eval uación triádica.

\section{Introduction}

Motivation is vital in order to enhance learning into its maximum potential (Vibulphol, 2016). In certain occasions, the mistake is thinking that the activity recreated is the predominant factor in getting the students involved in the learning process (Clinton $\&$ W ilson, 2019). However, the true essence of a training mechanism lies in the establishment of coherent methodological processes that have a solid and cohesive pedagogical basis behind them. Although this is a fundamental pillar in the current education system, it becomes even more relevant in Physical Education (PE), where student learnings have a wide impact on their day to day attitude and actions outside the classroom

Fecharecepción: 02-09-20. Fechadeaceptación: 27-10-20

Daniel Bores-García

daniel.bores@urjc.es
(M avropoulou, Barkoukis\& Douka, 2019).Theselearned behaviors not only refer to the level of adherence to physical activity, but also to other factors closely related to the psycho-evolutionary environment, such as their level of social relationships, self-esteem, self-concept or resilience (Karaday \& Ilker, 2018).

Therefore, the motivation of the student, in its broadest sense, is the most pursued goal by any teacher. Regardless of the teaching approach that PE teachers use in his or her classes, student involvement towards what they are taught is the most significant variable (H ortigüela-Alcalá \& Pérez-Pueyo, 2016). Educating the body includes attending to a large number of variables that are attached to each student previous experiences (Yüksel \& Tuncel, 2017). Consequently, in order to achieve motivation there is a series of aspects that must betaken into account, such as the enjoyment of activities, the promotion of competitiveness, the autonomy to carry out tasks, and the establishment of a positive 
environment (Holt, Smedegaard, Skaw-Pawlowski, Skovgaard \& Christiansen, 2019). These variables, which are part of the basic psychological needs according to the Self-D etermination Theory (Deci \& Ryan, 2000), will administer students an intrinsic motivation (Davies, Nambiar, Hemphill, Devietti, Massengale \& M cCredie, 2015) that will arrange a connection of what is learned with a diversity of previous bodily experiences.

Evaluation is an important area in the methodology of PE teachers, understanding it as a tool that has to be addressed in a pedagogical way in order to generate a sense of competition in students (Hortigüela-Alcalá, Palacios \& López-Pastor, 2019). In order to effectively incorporate methods based on student motivation, it is essential to involve them actively (Tolgfors, 2019). When this is accomplished, the implementation of formative and shared assessment processes have shown that they create a greater awareness in students about what they learn, as well as a greater capacity to selfregulate their tasks over time (Jing, 2017). Here is where the concept of triadic assessment arises, that consists of a triple assessment approach that combines self-assessment, peer-assessment, and teacherassessment in the same instrument, before a final grade, and on a given assessment procedure (Pérez-Pueyo, Hortigüela-Alcalá, Gutiérrez \& Hernando-Garijo, 2019). 0 ther aspects that directly influence the motivation of students towards the subject are: their previous experiences, the role played by the teacher, the dynamics applied in the classroom, and the contents addressed. Regarding the above, those linked to the field of body expression are those that generate the most discrepancies among students, especially in terms of gender, so it is necessary to seek strategies that adapt to the conditions of the students (Carriedo, M éndezGiménez, Fernández-Río, Cecchini, 2020). Girls with previous experience in artistic and expressive activities tolerate better these contents, while boys who practice sports value them the least. Body culture, excessively linked to physical condition and sports, has a great influence on this type of performance, denouncing the expressive version of the body and associating it with introspective behavior that leads to shame and ridicule around body image (Kerner, Haerens \& Kirk, 2018). $W$ ithout a doubt, this is a very socially stereotyped content that PE teachers have to reflect and act upon.

This article focuses on the motivation of PE students based on two important aspects, evaluation and body expression. The goal of the research is to analyze the motivation and commitment of students towards body expression contents in which formative and shared assessment have been applied through the use of triadic evaluation. Thisisasignificant contribution to the existing literature on the subject, since it analyzes the motivation of studentsin relation to the contents of body expression by implementing the formative assessment, more specifically, the triadic assessment.

\section{Body expression and evaluation: two controversial issues in PE}

PE is a subject that is highly influenced by past traditions as well as socio-cultural aspects that emanate from the matter in hand, which are also related to the dominant ideologies and discourses. This determines the construction of the corporal thoughts of teachers themselves (González-Calvo, H ortigüela-Alcalá, Fernández-Balboa, 2020). Although the rigor of teacher's training has increased considerably in the last decade, there are still conflicting positions on what its aims are and how it should beapproached in theclassroom, clearly questioning its competence (Pérez-Pueyo, VicentePedraz \& Hortigüela, 2019). Consequently, there is no better innovation than focusing on the transformation of those educational realities that generate issues in the subject.

Corporal expression and evaluation are two of the most problematic themes. The best way to solve these conflicts is to search for teaching approaches to provide solutions to the main obstacles that have emerged over time (Luttenberg, M eijer \& 0 olbekkink-M archand, 2017). Regarding to corporal expression, and according to the same authors, some of these are: a) not developing content that is associated with the collective achievement of the class; b) not generating satisfaction in one's own corporal experiences; c) not implanting coherent proposal sw ith a sense of longitudinal character. The last one mentioned is one of the main limitations of the projection of these contents, because since they are not applied with a certain logic and continuity, they restrict the obtention of learning results associated with the interventions carried out ( $M$ attsson $\&$ Lundvall, 2015). From this standpoint, it becomes especially complex to generate positive experiences in students due to the lack of special relevance given by the PE teacher himself (MacLean, 2018).

On the other hand, evaluation is one of the elements that generate most controversies. 0 ne of its major dilemmas is the approach teachers use to evaluate (Hortigüela-Alcalá, Pérez-Pueyo \& González-Calvo, 
2019). The fact that teachers should evaluate without the need of a grade has provoked many dissonances. Assessment has to go hand in hand with learning in PE, therefore, evaluation has to be used in a transparent manner and clearly integrated with the teaching processes in order to enhance student involvement (H ortigüela-Alcalá, Pérez-Pueyo \& López-Pastor, 2015). Another problem lies in the use of evaluation as a mechanism of teacher power: «l am theonewho knows, I am the one who sets the grade». W hen this happens, the essence of teaching is lost, since students are not allowed to be an active element of a process in which they form a substantial part. This creates a lack in the necessary pedagogical dimension, creating a big impact in the results, since they only meet physiological criteria and are strictly based on motor performance. This has an influence in the value that teachers give to their own body, with certain tensions and expectations regarding the typology of the body and itsinfluence on professional development (González-Calvo, Varea \& MartínezÁlvarez, 2019). W ith reference to this, formative and shared assessment processes are shown to be ideal for the use of assessment as a tool that enhances: a) selfregulation and awareness of learning from students; $b$ ) extrapolation of learning to a variety of contexts (Chng \& Lund, 2018)

Currently, there are many evidences that show that within PE, both body language and assessment are two elements where fur ther work and research are needed. Here is where the principle of «reason in action» (Tardif $\&$ Gauthier, 2008) has an important role, since it advocates the implementation of reasoning processes by teachers solve what happens in the classroom. The present article is focused on this idea, in which an intervention in PE is approached based on the formative evaluation, analyzing the motivation of the student towards the contents of corporal expression.

\section{Material and method}

\section{Participants}

The following study involved 182 students ( 95 boys and 87 girls) aged between 12-13 years old, who belonged to the seven groups of the first year of secondary education in a public high school in M adrid (Spain). The research was carried out in the Physical Education context, taught by the usual teacher ( 33 years old), PhD in Education and with ten year s of experience in teaching Thisteacher is one of the researcher sof the study, which allows us to guarantee the validity of the applied design and a more detailed and in-depth knowledge of the results obtained (Taylor \& Bogdan, 1986).

\section{Instruments}

Three instruments were used for data collection. Firstly, each student kept a personal diary during the development of the teaching unit. This was a semistructured diary with some suggested questions for each of the four sessions in which the students were asked to complete (Table 1).

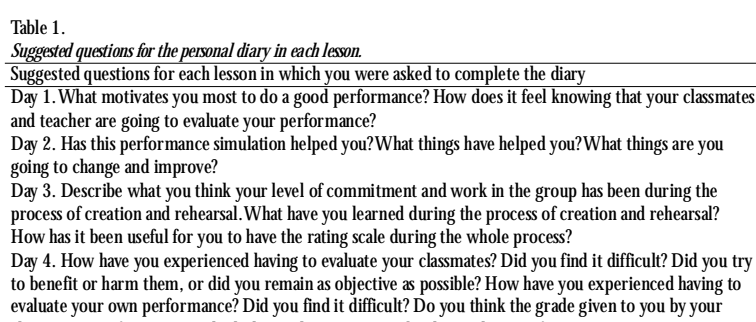

Secondly, the teacher completed a classroom diary in which he summarized the most significant aspects of what happened in the sessions, such as the student's response to the teacher's information, intra and intergroup interaction, or the degree of participation of all the members of the group. Finally, a discussion group was held in which 5 students decided to participate voluntarily at the end of the process. Following a semistructured design, the dialogues revolved around some questions suggested by the teacher, related to the objectives of the study and the rest of the instruments (Table 2). This discussion group, which lasted around 45 minutes, took place by videoconference using the Google Meet application, due to the interruption of face-toface classes as a result of the COVID-19 virus.

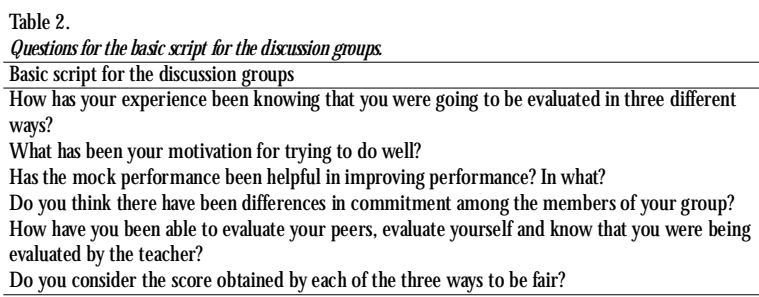

\section{Design and Procedure}

In this paper we used a qualitative methodology (Denzin \& Lincoln, 2000) framed within an interpretative approach (Albert, 2007; Stake, 2010) in which the most relevant information from the interpretation of the phenomenon under study is communicated ( $Q$ uintanal \& García, 2012). The research has been structured in four different phases, from J anuary to March 2020.

Phase 1: design and implementation of the didactic 
unit (Table 3), carried out from January to M arch, with a total of 10 lessons. During the first lesson the teacher explained the operating mechanics of the didactic unit, the contents dealt, and the evaluation procedure. Due to the fact that the groups were formed by students from the first year of secondary education, they were not familiar with the formative and shared evaluation, since they come from a different educational stage. Hence, the teacher briefly explained the difference between evaluation and qualification and the process by which a continuous evaluation of the learning would be carried out throughout the unit, with the purpose of being able to reach the objectives established for the unit. Lessons 2 and 3 consisted of introductory group activities associated to body expression, including imitation, interpretation, and improvisational tasks. Emotional expression activities were also accomplished using only the face, and al so the body in an integral way. Lesson 4 was completely dedicated to the formation of the groups and the explanation of the rating scale that would be used to evaluate and grade the group performance. This performance had a totally free theme, whose objective was to tell a story using non-verbal language together with the rest of the team members. The students had ten minutes to get together following two criteria established by the teacher: the groups should be between 4 and 5 members, and they should beformed by at least two boys and two girls. Almost all the students were able to group themselves according to the grouping criteria. Those who were not able to do so in the prescribed time were helped by the teacher so that the groups were balanced in number and in gender heterogeneity. The teacher then proceeded to explain the rating scale, giving several copies to each group. He explained what each of the assessable elements consisted of (storyboarding, creative capacity, narrative capacity, expressive capacity, respect for time limits and fluidity and coordination among group members) and the different degrees of compliance that could be achieved in each of them. Students were asked to bring the scale of assessment throughout the process of creation and preparation of the performance, as it would serve as a reference for the work. In lessons 5, 6 and 7 each group worked independently, managing time and distributing tasksin afree and consensual way. The teacher supervised the work of each group and offered help and feedback on a continuous basis. Lesson 8 consisted in the representation of the performances, after which the triadic evaluation was put into practice. Based on the assessment scale (Table 4), each group had to evaluate its own and the rest of the groups' representations according to the different levels of achievement for each of the assessable items. The teacher also performed an evaluation for each group. O nce the evaluations were made, a small debate was formed in order to discuss what had been learned and to establish lines of improvement for the final representation. Lesson 9 was entirely dedicated to the correction of the errors detected in the previous session, using the evaluation scales filled in by the teacher, by the group itself and by the rest of groups. The last lesson was dedicated to the final representation of the performances, evaluating again in a triadic way each one of them and providing a grade using the values given to each evaluable element and obtaining a final grade resulting from the weighted average of the self-assessment (33.3\%), the peerassessment (33.3\%) and the teacher-assessment (33.3\%). A similar experience in the previous year showed that there is not much difference between the results of the three types of assessment (Bores-García, 2019).

Phase 2: design and completion of the student's diary and the teacher's diary. The students completed four days at home (Day 1, Day 2, Day 3 and Day 4), corresponding to the time after lessons 1, 8, 9 and 10, respectively. These four sessions were chosen because of the content dealt with in them, which gave rise to the questions asked of the students so that they could fill in the personal diaries. In the following lesson they had to hand in the finished diary to the teacher.

Phase 3: design and for mation of the discussion group. O nce the didactic unit is finished, the discussion group is carried out by 5 volunteer students. Participating in the discussion group required a commitment from the student volunteers to attend. This requirement, coupled with the embarrassment that many students experience in having to explain themselves in front of peers and the teacher knowing that the conversation is being recorded, meant that there were only five volunteers, a good number to conduct a discussion group in which everyone could participate.

Phase 4: analysis of the data obtained adopting the three instruments. 0 nly 30 student diaries were duly completed according to the requirements indicated by the teacher (legible handwriting, correct wording, minimum length of 10 lines, delivery within the established deadline), so only these were analyzed. These requirements were established in order to obtain the richest and deepest information possible, avoiding that the answers of the students were too short and without 
any contribution to the purposes of the research. In addition, a deep reflection was made on the objectives of the study and the procedure carried out in it.

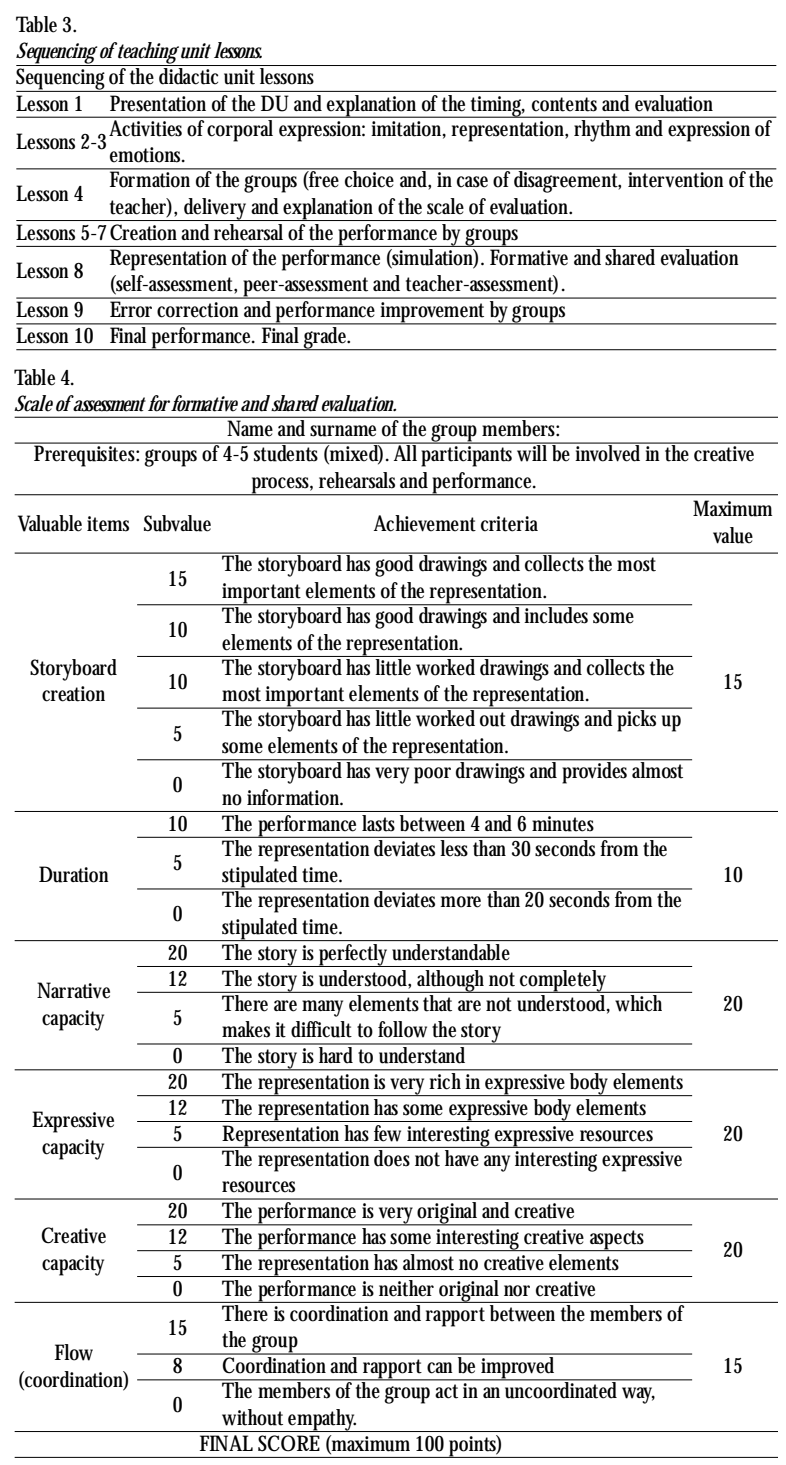

Express permission was given by both the management team of the school and the families, who were informed of the content and objectives of the study. 0 ne of the positive aspects of the procedure is the scarce interference that the research had in the previously established teaching-learning process, being able to follow the didactic program normally.

\section{D ata analysis and categorization}

Based on the thematic analysis strategy (Braun \& Clarke, 2006) the data is organized in five blocks presented in a random order of presentation, as no hierarchy is intended: (a) motivational aspects to face the task, (b) usefulness of performance simulation using shared assessment, (c) perception of the level of individual and group commitment, (d) lessons learned, and finally (e) the use of triadic assessment and the jump to rating 0 ne of the authors of the paper has led this process of data analysis, and another has adopted the figure of the critical friend (Smith \& McGannon, 2017) who has reviewed the analysis and encouraged a dialogue between the authors, giving consistency, rigor, and credibility to the analysis (Beltrán-Carrillo $\&$ DevísDevís, 2019).

The five resulting blocks, which make up the five categories of analysis, in addition to being related to the objectives of the research, emerge from the saturation of coinciding data and ideas, and the thematic axes treatment (Hortigüela-Alcalá, González-Calvo \& PérezPueyo, 2020). These categories are represented in the three data collection instruments used (student diaries, teacher diaries and discussion groups), thus ensuring through inter- and intrainstrument triangulation the essential coherence and particularity in all research (Trainor \& Graue, 2014). In order to guarantee the transferability, credibility and reliability of the results, a codification of the most significant extracts from the three data collection instruments has been carried out, making use of cross matching patterns (Saldaña, 2006).

3.5. Codification of data collection instruments

Different acronyms have been used to facilitate the identification of the extracts from the original instrument. Thus, for the student's personal diary the acronym (SPD) is used, for the teacher's diary the acronym (TD) is used, and for the focus groups the acronym (FG, number of the student) is used.

\section{Results}

The results are shown according to the categories generated from the data obtained from the instruments and in relation to the objectives of the study. For length reasons, in each category only the most significant text extracts are presented.

\section{Motivational aspects to face the task}

$O$ ne of the most predominant motivations of the students is the possibility of working in groups with colleagues with whom they have a good relationship, since the teacher has given them the freedom to organize the groups autonomously.

«W hat motivates me most is that, for once, I'm in the group with people I like and they're my friends) (SPD)

«I'm very motivated with my group, becausel love who I'm with. They're good partners.» (SPD)

«At first, there was nothing that motivated me... but when 
we did the groups I was able to work with the ones I wanted and that motivated me quite a lot.» (SPD)

"One of the things that made them most excited when I explained the working procedure was when I told them that they would have a few minutes to form their own groups, as long as they respected the grouping criteria» (TD)

«What motivated me most about the unit was being able to be with the people we wanted.» (FG, student 2)

This grouping strategy increases the anticipation of fun from students which, although it may present some disadvantages from the point of view of class control, facilitates student participation by increasing their motivation.

«...also I'm with my friends and have a great time with them» (SPD)

«It motivates methat I'm going to have fun and spend more time with my friends.» (SPD)

The data reflects the desire students have to achieve agood grade in the teaching unit, even if the contribution of this activity to the overall grade of the course is not too significant.

"The mark also motivates me, because I want to get a good mark like in the first evaluation» (SPD)

"Knowing that two thirds of the grade came from what we put about ourselves and the grade our classmates put on us, that was quite motivating» (FG, student 5 )

The triadic evaluation procedure is accepted by the students in a heterogeneous way. In one hand, they recognize that this type of assessment offers a more global vision of the learning outcome.

"The grade at the end seems to be more fair from a coll ective point of view» (SPD)

$\mathrm{O} n$ the other hand, being evaluated by the teacher gives them security, since there is a certain distrust towards the possibility of being evaluated and qualified by peers:

"Thefact that the teacher evaluates me is reassuring because he has specialized in this career and knows what he's talking about. The fact that my classmates evaluate me does not make me enthusiastic either, since we could evaluate them unfairly» (SPD)

«I'm a little nervous about being evaluated by my peers because they might try to hurt me and not give me the grade I deserve» (SPD)

«We're not experts in body language. The teacher is the only one who knows what is right or wrong. What we or our classmates say can be wrong.» (FG, student 1)

The last motivating factor is strongly tied to content. A sector of the studentsfeels rejection towards the more sportive or physical condition contents, but they feel a lot of attraction for the expressive aspects, therefore increasing their motivation towards this didactic unit.

«I was a bit fed up with handball and athletics. I love theatre and that makes me want to do my best for the first time in the course» (SPD)

«l like being able to show that physical education is more than just sport» (SPD)

«The requirement of developing a storyboard for the performance has activated the motivation of some less motorically involved but artistically gifted students who see, at last, how they can be of great help to their group» (TD)

\section{U sefulness of performance simulation using shared evaluation}

The representation of lesson 8 in which a simulation of triadic evaluation is made is very positively valued by the students. This simulation method contributes to increasing the possibilities of improvement.

«It has helped me a lot to analyze our failures and to fix them for the final performance» (SPD)

«Being able to ask our colleagues what we did wrong has allowed us to change several things for the final performance» (SPD)

«Being able to do a performance test before the final was very good for us to know what things we needed to improve and make it perfectly in the final assembly» (FG, student 4)

«Although due to time constraints we were not able to stop as long as we would have liked to give feedback and have each group evaluate themselves, it is obvious that all groups were awarethat therewere quitea few thingsthey could still improve» (TD)

There were coincidental opinions that this performance simulation has helped them to face the final lesson with more confidence, due to the possibility of having previous acting experience in front of peers and the teacher before the final performance.

«Because you've already performed in the simulation, you feel safer and more confident to do it in front of everyone» (SPD)

«It's hel ped me to get used to performing in public, because it's not the same to do it when everyone is looking at you» (SPD)

The use of the rating scale in this session facilitates the interpretation of the improvement areas for the final performance, which takes place two sessions later.

"The rating scale has been very useful to see where the failures were and what we could do to correct them» (FG, student 3)

"Some of the students didn't read the rating scale carefully, even though we spent almost a whole lesson reading and 
explaining it. N evertheless, assessing themselves and their peers has been good for the next two sessions» (TD)

\section{Perception of the level of individual and group commitment and learning obtained}

Theperception about the level of individual and group commitment is heterogeneous. Some of the students point out this aspect as positive during the whole process:

«All my classmateshaveal so committed themselvesand worked just as hard as I did» (SPD)

"... We even have aWhatsApp group to talk and discuss the failures...» (SPD)

"At first we were all a little bit off, but then we started working and we were very much into the project» (FG, student 3)

"The overall level of involvement has been high. Having shared elements such asa common project, a common evaluation and a common rating has served as an incentive for individual and group commitment» (TD)

0 ther students, however, admits they weren't sufficiently committed or reproaches colleagues in their group for lack of commitment.

«I have to admit that I laughed all the time in the first rehearsals... although I took it seriously afterwards» (SPD)

"There are people who had a hard time taking the piss out of it.» (SPD)

«There were some in my group who were laughing their heads off.» (SPD)

"As always, there is a small percentage of students with little motivation for the task (and for everything in general too, almost always) who either blow up the work of others or remain absent, blowing it up anyway. This has more frequently in groups of students who have not been able to group with whomever they wish, resulting in a group that is too heterogeneous, with students who are more marginalized in the class and, therefore, more unmotivated» (TD)

\section{Learning from the process}

The learning has been more attitudinal than technical, as far as body expression is concerned. Although there are some students who claim to have improved expressive resources or communication of emotions through gestures, most of them refer to a more relational type or socially related learning.

«It has helped me to get to know better my classmates and realize that some people are not what they seem, because they can bevery funny, intelligent, and even very good people» (SPD)

«I'velearned that even if you don't get al ong with a partner, you're going to have to adapt.» (SPD)

«During the process of creation and rehearsal I havelearned to listen» (SPD)

«I have expressly decided not to give so much importance to expressive content, but to use it as a tool to achieveother elements of equal or greater value such as respect for oneself and others, effort, mutual commitment, honesty, and transparency» (TD)

\section{Triadic evaluation and scoring}

The rating scale has played a very relevant role throughout the process, from the first day when the instrument was explained, to the last day when it was used to evaluate and rate.

«It has been useful for me to check if my group and I were doing things right and how we could improve some things» (SPD)

"Giving importance to the rating scale has been a hard task for me, I admit. They're not used to using paper and pencil in P.E. Somegroupsforgot to bring thegrading scaleto the rehearsals and I got tired of reminding them of its importance. But in the end I think it has been very useful for them» (TD)

The triadic assessment has been an odd addition for the vast majority of students, who have not harnessed this procedure during their time in primary education. Both peer-assessment and self-assessment have presented certain difficulties to students.

«Evaluating my classmates has been a littledifficult, because while I wanted to help them I also wanted to be objective» (SPD)

«Assessing my own performance was strange to me, because we didn't see what we were doing ourselves) (SPD)

However, the possibility of taking as a criterion what is stated in the rating scale has brought some relief.

«With the rating scale it has been easier to evaluate my colleagues and myself» (SPD)

«Following the sheet (rating scale) has helped me stay objective» (SPD)

«W ith the assessment sheet it was very easy to know what to assess.W W thout that sheet we would have looked at other things》 (FG, student 4)

Justice and injustice has been a matter of debate in the qualification process. 0 bjectivity is associated with justice and subjectivity with injustice.

«The teacher's grade did seem fair to me because it was the most objective of all» (SPD)

«I think we've been fair in putting it down because we've been as objective as possible.» (SPD)

«I recognize that we gave a higher grade to ourselves than what we deserved, to hel p usi The professor'sgradewas thefairest.» (FG, student 2)

The results in terms of the score obtained by the groups do not differ much between the three types of 
evaluation, as it already happened in the same experience carried out in the same center the previous year.

«D espite being groups with little previous experience in formative and shared evaluation, the final results in terms of grades have been quite balanced. Self-assessment has been somewhat superior to peer-assessment and teacher-assessment, but with little difference» (TD)

\section{Discussion}

Taking as a reference the Self-D eterminationTheory (Deci \& Ryan, 2000; Davies, et al, 2015) the results of the previously shown study reflect the importance that students give to the basic psychological needs as a positive influence in their motivation towards the content of body expression in particular. The possibility of choosing one's teammates in the group represents one of the most motivating factors, hence covering the need for relationship (Erturan-Ýlker, Yu, Alemdaroglu \& Köklü, 2018). Thus, working in groups where there is a good interpersonal relationship generates a playful expectation in students that considerably increases their motivation towards the task, in line with what has been pointed out by Baena-Extremera, Gómez-López, Granero-Ga llegos \& Martínez-Molina (2016). The existence of a common project, in this case the elaboration of a final assembly, acts as an element of group cohesion and gives a specific meaning to group work that increases the feeling of belonging and interdependence, favored by a role of the teacher that is not very controlling and promotes autonomy in the particular processes of each group (De Meyer, Soenens, Aelterman, De Bourdeaudhuij \& Haerens, 2016). This autonomy is mediated by the freedom that teachers give to students to make their own decisions, thus increasing their motivation for the task (Reeve, 2006), a fact that is greatly facilitated by the possibility that work on expressive content gives to the use of creative methodologies in which students have large plots of decision and self-regulation capacity (M onfort-Pañego \& Iglesias-García, 2015). As the contents of body expression are traditionally welcomed with more enthusiasm by girls ( 0 'N eill, Pate $\&$ Liese, 2011), the proposal presented provokes a great acceptance in the students who do not feel attracted by the majority contents in PE, such as sport or physical fitness. The prospect of spending several weeks working on a different content generates an increase in students' perceived competence, by carrying out activities for which they feel qualified, and in their achievement satisfaction, by checking that they can meet the teacher's expectations and the activity satisfactorily (Holt, et al., 2019). Therefore, the fulfillment of the three basic psychological needs contributesto an increase of intrinsic motivation (Lukwu \& Guzmán, 2011), favoring a positive climate in the classroom that constantly feeds back this motivation and, therefore, learning.

The results show, aligned with the work of LópezPastor, Sonlleva-Velasco \& M artínez-Scott (2019), that students confuse assessment with grading $W$ hen asked about the evaluation processes, their answers go directly to the grade. However, evaluation should be understood by students -also by teachers- as an essential element to attain real learning (Chiappe, Pinto \& A rias, 2016). The way in which the formative assessment was used during the process allowed the students to be more focused on the task (Chng \& Lund, 2019), knowing that they would have two chances to show their work to the rest of their classmates and to the teacher, while receiving feedback to improvetheir expressive production. According to recent studies, it has been clearly indicated that the application of formative assessment processes in PE is advisable in order to promote student learning (Chng $\&$ Lund, 2018). This learning requires the use of instrumentsthat allow students to self-regulate (D uncan \& Buskirk-Cohen, 2011), which occursmost effectively when the possibility of implementing triadic assessment strategies is offered (Hortiguela-Alcalá, Pérez-Pueyo $\&$ A bella, 2015). Thus, the use of the assessment scale as an instrument for formative assessment during the development of the entire teaching-learning process favored the knowledge not only of the students' potentialities, but also of their limitations (J oughin, Dawson \& Boud, 2017), allowing students to improve their expressive production from the feedback received. This feedback, traditionally coming exclusively from the teacher, was the result of a triadic evaluation process in which the students themselves, together with their peers and the teacher, valued the process, thus allowing for a rich variety of feedback channels (Wanner $\&$ Palmer, 2018). Furthermore, the students acknowledge the assessment scale as a useful tool, and as an element of initial and continuous information on the most important aspects of the process. According to Alonzo's work (2018), it is essential to know in advance what the criteria for evaluating the teaching-learning process will be, as well as the key elements of the process, so that students are aware of what the teacher is expecting from them. 
W hen jumping to the grading step in the last session of the teaching unit, the final grade of the students depends equally on the self-assessment, the peerassessment and the teacher-assessment. The students consider the teacher's grade to be the fairest because he or she is the expert on the content, although most of them admit to having made an effort to be as fair as possible. However, according to the existing literature, what would be unfair would be precisely not having students in the assessment process (Santos, 2014). In this case, grading is just one part of a large process of assessment that has to be specifically oriented toward improving the teaching-learning process (Hamodi, Moreno \& Barba-Martín, 2018).

The educational proposal in which this research is based requires students to work in small groups. According to the results obtained, students are generally satisfied with both their individual and group commitment and acknowledge having tried to give their best, thereupon increasing the intrinsic motivation of all group members (Keely, 2016). The teacher gives students a great deal of freedom to make their own decisions and to regulate their creative process. The students perceive this confidence from the teacher increased their level of commitment to the task (Archilla-Prat \& Pérez-Brunicardi, 2017). A high level of group development and autonomy was demonstrated from the students, asthe methodological processisbased on an intentional formative and shared evaluation that prioritizes the dialogical processes among the team members and guides the didactic progression towards constant learning in community (Tolgfors, 2018).

\section{Conclusions}

The contents of body expression have traditionally been theAchilles' heel of the teaching of PE. N onetheless, this study has shown how the application of formative and shared assessment positively influences student motivation and the level of individual and group commitment. Assessment must be associated with and oriented to learning, separating it from the reductionism that has traditionally assimilated it to qualification. Students must know from the beginning of the teachinglearning process what is expected from them, what acquirements they must develop, and how they will be able to progressin it. Formative assessment accompanies students throughout this process, and shared assessment allows them to increase feedback channels in such way that they can handle much richer and more relevant information while taking into account different points of view. The free choice of group mates, the own system of work in small groups and the freedom in the construction of the performance increases the level of motivation of the students. Sharing a common project develops the students' sense of belonging and interdependence, increasing al so their level of autonomy by being able to make their own decisions and selfregulate their progress. Despite the increasingly frequent use of formative and shared evaluation processes, many students continue to confuse the terms evaluation and scoring, treating them as synonyms and stripping evaluation of its formative character. The students are satisfied with the level of individual and group commitment, thanking the trust that the teacher places in them, which increases their feeling of competence and their motivation for the task. 0 ne of the limitations of the study is the short duration of the implementation of the formative and shared evaluation process, suggesting for future research an experience that can cover two or more consecutive didactic units. It would also be interesting to compare these results with those that would result from applying this type of evaluation in higher courses. More studies are needed that address expressive content from a constructive perspective, trying to give them the value they deserve within the curriculum of the subject and making it possible that, through them, students can build meaningful learnings for life.

\section{References}

Albert, M.J. (2007). La investigación educativa. Barcelona: McGraw-Hill.

Alonzo,A. (2018). AnArgument for FormativeAssessment with Science Learning Progressions. Applied Measurement in Education, 31(2), 104-112. https:/ / doi.org/ 10.1080/ 08957347.2017 .1408630

Archilla-Prat, M .T., \& Pérez-Brunicardi, D. (2017). Laslucesdela expresión corporal. Ventajasy posibilidades de los «Proyectos deAprendizajeExpresivos» en Educación Físicaen Secunda ria. Retos, 31, 232-237. https:// doi.org/ 10.47197/ retos. V0i31.51065

Bæena-Extremera,A., Gómez-López, M., Granero-Gallegos, A., \& Martínez-M olina, M . (2016). Modelo de predicción dela satisfacción y diversión en Educación Físicaa partir delaautonomíay el climamotivacional. U niversitasPsychologica, 15(2), 15-26.

Beltrán-Carrillo,V.)., \& Devís-D evís, J. (2019). El pensamiento del alumnado inactivo sobresus experienciasnegativasen educa ciónfísica: losdiscursosdel rendimiento, salutismo y masculinidad hegemónica. RICYDE. Revista internacional decienciasdel 
deporte, 55(15), 20-34. https:// doi.org/ 10.5232/ ricyde2019.05502

Bores-García, D. (2019). Evaluación compartidaen lacreación y representación deuna composición teatral en laasignaturade Educación Físicaen Educación Secundaria. Revista Infancia, Educación yAprendizaje,5(2), 20-25. https./ / doi.org/ 10.22370/ ieya.2019.5.2.1428

Braun,V. y Clarke,V. (2006). Using thematic analysisin phychology. Qualitative Research in Psychology, 3, 77-101. https:/ / doi.org/ 10.1191/ 1478088706qp0630a.

Carriedo,A., M éndez-Giménez,A., Fernández-Río, J., \& Cecchini, J.A. (2020). Nuevasposibilidadesy recursos paralaenseñanza delaexpresión corporal en educación física:

Chiappe, A., Pinto, R., \&Arias,V. (2016). 0 pen Assessment of Learning: A M eta-Synthesis International Review of Research in Open and Distributed Learning, 17(6), 44-61.

Chng, L.S. \& Lund, J. (2019)Thelmpact of FormativeAssessment on the Success and Response Rate in a 6th Grade Physical Education Badminton U nit. International Journal of Kinesiology in Higher Education, 3(1), 12-22. 10.1080/ 24711616.2018.1509680

Chng, L.S., \& Lund, J. (2018). Assessment for Learning in Physical Education:TheW hat,W hy and How. Journal of Physical Education, Recreation \& Dance, 89 (8), http:/ / dx.doi.org/ 10.1080/ 07303084.2018.1503119.

Clinton,V., \&W ilson, N. (2019). M orethan Chalkboards: Classroom Spaces and Collaborative Learning Attitudes. Learning EnvironmentsResearch, 22(3), 325-344.

Davies, B., Nambiar, N., Hemphill, C., Devietti, E., Massengale, A ., \& M cCredie, P. (2015). Intrinsic M otivation in Physical Education. Journal of Physical Education, Recreation \& D ance, 86(8), 8-13. http:// dx. doi. org/ 10.1080/ 07303084.2015.1075922.

DeM eyer, J., Soenens, B., Aelterman, N., DeBourdeaudhuij, I., $\&$ Hæerens, L. (2016)T The differentfacesof controllingteaching: implications of adistinction between externally and internally controlling teaching for students' motivation in physical education, Physical Education and Sport Pedagogy, 21(6), 632652. 10.1080/ 17408989.2015.1112777

Deci, E. L., \& Ryan R.M. (2000). The what and the why of goal pursuits: Human needsand the self-determination of behavior. Psychological Inquiry, 11(4), 227-268.

Denzin, N. K. \& \& Lincoln,Y.S. (2000).Thedisciplineand practice of qualitative research. En NK Denzin Y YS Lincoln (Eds.), Handbook of Q ualitative Research, (1-28). London: Sage Publications.

Duncan, T., \& Buskirk-Cohen, A. (2011). Exploring learnercentered assessment: A cross-disciplinary approach. International Journal of Teaching and Learning in Higher Education, 23(2), 246259.

Erturan-Ýlker, G.,Yu, C., Alemdaroglu, U., \& Köklü,Y. (2018). Basic psychological needs and self-determined motivation in physical education to predicthealth-related fitnesslevel. Journal of Sport and H ealth Research, 10, 91-100.

González-Calvo, G., H ortigüela-Alcalá, D., \& Fernández-Balboa,
J.M. (2020). Foci and factors that contribute to physical educators' construction of their professional body subjectivities: aqualitativestudy. Sport, Education and Society, 25 (3), 292-304. doi: 10.1080/ 13573322.2019.1578206.

González-Calvo, G.,Varea,V., \& Martínez-Álvarez, L. (2019). Health and BodyTensions and Expectationsfor Pre-ServicePhysical EducationTeachersin Spain. Sport, Education and Society, 24(2), 158-167. doi: http:// dx.doi.org/ 10.1080/ 13573322.2017.1331426.

Hamodi, C., M oreno, J., \& Barba, R. (2018). M ediosdeevaluación y desarrollo de competencias en educación superior en estudiantes de Educación Física. Estudios Pedagógicos, 44 (2), 241257.

Holt, A. D., Smedegaard, S., Skaw-Pawlowski, C., Skovgaard,T., $\&$ Christiansen, L. (2019). Pupils' Experiences of Autonomy, Competence and Relatedness in 'M ove for Well-Being in Schools': A Physical Activity Intervention. European Physical Education Review,25(3), 640-658. http:/ / dx. doi. org/ 10.1177/ $1356336 \times 18758353$

Hortigüela, D. \& Pérez-Pueyo,A. (2016). Influenciadelaregula ción del trabajo del alumnado universitario en laimplicación hacialastareas. Psychology, Society \& Education, 8(1), 39-51.

Hortiguela, D. \& Pérez-Pueyo,A., \&Abella,V. (2015). Percepcionesdel alumnado sobrelaevaluación formativa: Contrastede grupos de inicio y final de carrera. REDU. Revista deD ocencia Universitaria, 13(3), 12-32.

Hortigüela, D., Palacios,A., \& López-Pastor,V. (2019).Theimpact of formativeand shared or coassessment on the acquisition of transversal competences in higher education. Assessment \& Evaluation in Higher Education, 44 (6), 933-945. 10.1080/ 02602938.2018 .1530341$.

H ortigüela, D. , Pérez-Pueyo, A., \& González-Calvo, G. (2019). Pero... ¿A qué nos referimos realmente con la Evaluación Formativay Compartida?: Confusiones Habitualesy ReflexionesPrácticas. Revista Iberoamericana de Evaluación Educativa, 12(1), 13-27. https:/ / doi.org/ 10.15366/ riee2019.12.1.001. H ortigüela-Alcalá, D. , González-Calvo, G.; \& Pérez-Pueyo, Á. (2020). ¿Por quéquiero ser profesor deEducación Física?Aná lisisdel cambio de percepción durantelaformación universita riaylos primerosañosdelacarreradocente. M ovimento, 26, 114.

H ortigüela-Alcalá, D., Pérez-Pueyo, A., \& López-Pastor, V. (2015). Student involvement and management of students' workload in formativeassessment in higher education. Relieve: revista electrónica deinvestigación y evaluación educativa, 21(1), 1-5. 10.7203/ relieve.21.1.5171.

http:// dx. doi.org/ 10.1007/ s10984-019-09287-w.

internet y los retosvirales. Retos, 37, 722-730. https:/ / doi.org/ 10.47197/ retos. v37i37.69147

Jing, M. (2017). U sing FormativeA ssessment to Facilitate Learner Self-Regulation: A Case Study of A ssessment Practices and Student Perceptions in Hong Kong Taiwan Journal ofTESOL, 14(1), 87-118.

Joughin, G., Dawson, P., \& Boud, D. (2017). ImprovingAssessment TasksthroughAddressing $\mathrm{O}$ ur UnconsciousLimitsto Change. 
Assessment \& Evaluation in Higher Education, 42 (8), 1221-1232. https:/ / doi.org/ 10.1080/ 02602938.2016.1257689

Karaday, E. , \& Ilker, G.E. (2018). Predictors of Self-Esteem in Physical Education: Self-Determination Perspective. International Journal of Psychology and Educational Studies, 5(2), 39-47.

Keely, P. (2016). FormativeAssessment Probes: Big and Small Seeds Linking FormativeAssessment Probesto the Scientific Practices. Scienceand Children, 53(9), 20-21.

Kerner, C., Hærens, L. \& \& Kirk, D. (2018). U nderstanding Body Imagein Physical Education: CurrentKnowledgeand Future Directions. European Physical Education Review, 24 (2), 255-265. http:/ / dx. doi.org/ 10.1177/ 1356336X17692508.

López-Pastor,V.M., Sonlleva-Velasco, M ., \& M artínez-Scott, S. (2019). Evaluación formativay compartidaen educación. Re vista Iberoamericana de Evaluación Educativa, 12(1), 5-9.

López-Pastor,VM, Sonlleva-Velasco, M ., \& M artínez-Scott, S. (2019). Evaluación formativay compartidaen educación. Re vista Iberoamericana de Evaluación Educativa, 12(1), 5-9.

Lukwu, R. M ., \& Guzmán, J. F. (2011). Sport commitment and adherence: A social-cognitiveanalysis. Revista Internacional de Cienciasdel D eporte, 25(7), 277-286.

Lukwu, R.M., Guzmán, J.F. (2011). Sport commitment and adherence: A social-cognitiveanalysis. Revista Internacional de Cienciasdel Deporte, 25(7), 277-286.

Luttenberg, J., M eijer, P., \& 0 olbekkink-M archand, H. (2017). UnderstandingtheComplexity of Teacher Reflection inAction Research. Educational Action Research, 25(1), 88-102. http:/ / dx.doi.org/ 10.1080/ 09650792.2015.1136230.

MacLean, J. (2018). Teachers asAgents of Change in Curricular Reform:The Position of Dance Revisited. Sport, Education and Society, 23(6), 563-577. http:/ / dx. doi.org/ 10.1080/ 13573322.2016.1249464.

Mattsson,T., \& Lundvall, S. (2015).ThePosition of Dancein Physica Education. Sport, Education and Society, 20 (7), 855-871. http:/ / dx.doi.org/ 10.1080/ 13573322.2013.837044.

Mavropoulou, A., Barkoukis, V., D ouka, S., Alexandris, K., \& Hatzimanouil. (2019). The Role of Autonomy Supportive Activitieson Students' M otivation and Beliefstoward 0 ut-ofSchool Activities. Journal of Educational Research, 112 (2), 223233. http:/ / dx.doi.org/ 10.1080/ 00220671.2018.1503580.

0 'N eill, J.R., Pate R.R., \& Liese, A.D. (2011). Descriptive epidemiology of dance participation in adolescents. Research Quarterly for Exerciseand Sport, 82 (3), 373-380. https: / / doi.org/ 10.1080/ 02701367.2011.10599769

0 'Neill, J.R., Pate, R.R., \& Liese, A.D. (2011). Descriptive epidemiology of dance participation in adolescents. Research Quarterly for Exerciseand Sport, 82(3): 373-380. https: / / doi.org/ 10.1080/ 02701367.2011.10599769

Pérez-Pueyo, A., Hortigüela-Alcalá, D., Gutiérrez, C., \& Hernando-Garijo, A. (2019). ¿Andamiaje y evaluación formativa: doscarasdelamismamoneda? Infancia, Educación y Aprendizaje, 5(2), 559-565.

Pérez-Pueyo, A.,Vicente-Pedraz, M ., \& H ortigüela, D. (2019). ¿Por quéy paraqué de lascompetencias claveen educación
física?A Anál isis de dos posturas contrapuestas. Retos,35, 7-12. https: / / doi. org/ 10.47197/ retos. v0i35.60646

Quintanal, J., \& García, B. (2012). Fundamentosbásicosdemetodologíadeinvestigación educativa. Madrid: CCS.

Reeve, J. (2006). Teachers as Facilitators: W hat AutonomySupportive Teachers Do andW hy Their Students Benefit. Elementary School Journal, 106, 225-236.

Sal daña, J. (2009). The coding manual for qualitative researchers. Thousand 0 aks: Sage.

Santos, M. (2014). La evaluación como aprendizaje, cuando la flecha impacta en la diana (2ª̈Ed. ). M adrid: Ed. N arcea.

Smith, B., \& M cGannon, K.R. (2017). Developing rigor in qualitative research: Problemsand opportunitieswithin sport and exercisepsychology. International Review of Sport and Exercise Psychology, 11(1), 101-121. https:/ / doi.org/ 10.1080/ 1750984X.2017.1317357

Stake, R. (2010). Q ualitativeResearch. Studying how thingswork. NewYork:The Guilford Press.

Tardif, M ., \& Gauthier, C. (2008). El maestro como «actor racional»: racionalidad, conocimiento y juicio. En Paquay, L. et al. (Coords. ). La formación profesional del maestro. Estrategiasy competencias (pp. 309-354). México, DF: Fondo deCulturaEconómica.

Taylor, S. J., \& Bogdan, R. (1986). Introducción a los métodos cualitativosdeinvestigación. Barcelona: Paidós.

Tolgfors, B. (2018) Different versions of assessment for learning in the subject of physical education. Physical Education and Sport Pedagogy, 23(3), 311-327, DOI: 10.1080/ 17408989.2018.1429589

Tolgfors, B. (2019). Transformative Assessment in Physical Eduction. European Physical Education Review,25(4), 1211-1225. doi: http:/ / dx.doi.org/ 10.1177/ 1356336X18814863.

Trainor, A., \& Graue, E. (2014). Eval uating rigor in qual itative methodology and research dissemination. Remedial and Special Education, 35(5), 267-274.

Vibul phol, J. (2016). Students' Motivation and LearningandTeachers' Motivational Strategies in English Classrooms inThailand. English LanguageTeaching, 9(4), 64-75.

Wanner, T., \& Palmer, E. (2018). Formative Self- and Peer Assessment for Improved Student Learning: The Crucial Factors of D esign, Teacher Participation and Feedback. Assesment \& Evaluation in Higher Education, 43(7), 1032-1047. https:/ / doi.org/ 10.1080/ 02602938.2018.1427698

Yüksel, H.S., \& Tuncel, F. (2017). Experiences of 5th Grade Students Participating in Active Gaming-A ssisted Physical Education Lessons. Journal of Education andTraining Studies, 5(13), 19-31. 